\title{
Searching for natural herbicides in methanol extracts of eight plant species
}

\author{
Ragab A. El-Mergawi ${ }^{* *}$ and Abulrohman I. Al-Humaid ${ }^{2}$
}

\begin{abstract}
Background: Plant extracts could turn out to be natural herbicides to be used in weed control. This study was conducted to study the phytotoxic effects of methanol extracts obtained from Tamarix mannifera, Alhagi maurorum, Echinops spinosissimus, Haloxylon salicornicum, Lactuca virosa, Neurada procumbens, Ochradenus bacctus, and Cyperus conglomerates plants on germination and growth of Phalaris minor, Echinochloa crusgalli, Portulaca oleracea, and Lactuca sativa.

Results: In laboratory trial, extracts of eight plants at 0, 5, 10, 20, and $40 \mathrm{~g} / \mathrm{L}$ were evaluated on germination of seeds of four target species. The inhibitory effect of tested extracts varied among the examined seeds, and $P$. minor was the most sensitive. Extracts of T. mannifera and L. virosa showed the greatest effect on seed germination and seedling growth of studied seeds. Using the extract of T. mannifera at $40 \mathrm{~g} / \mathrm{L}$ completely inhibited the germination and seedling growth of $P$. minor and shoot length of $P$. oleracea as well as root length of E. crusgalli and L. sativa. At this concentration, L. virosa nearly had a complete inhibition effect on germination and seedling growth of $P$. minor and $P$. oleracea. In the greenhouse trial, extracts from tested plants at four concentrations $(0,30,60$, and $90 \mathrm{~g} / \mathrm{L})$ were used in a phytotoxic bioassay against 6-week-old L. sativa and three target weeds. The growth of 6-week-old weeds tended to be less sensitive to the tested extracts than the weed germination. The significant injury effect was observed only when T. mannifera extract at 60 and $90 \mathrm{~g} / \mathrm{L}$ was sprayed on P. minor, E. crusgalli, and L. sativa plants.
\end{abstract}

Conclusions: Among tested species, T. mannifera and L. virosa could be used for developing new natural herbicide.

Keywords: Allelopathy, Natural herbicide, Germination, Tamarix mannifera, Lactuca virosa

\section{Introduction}

In an attempt to reduce the use of synthetic pesticides, extensive investigations into the possible exploitation of plant compounds as natural commercial products have been undertaken over the past two decades (Masum et al. 2016; Trezzi et al. 2016). Natural herbicides could offer new alternatives to synthetic herbicides. For many years, allelopathy research was conducted to study the effects of crude extracts on crop yields and weeds suppression under laboratory and field conditions (Putnam and Tang 1986). The use of plants with strong allelopathic properties for weed control has shown promising results. Bioassay has been used in the selection of plant species and extraction processes for the extracts in the search for a product with the highest phytotoxicity (Gomes et al. 2016; Rawat et al. 2017). Recently, crude extract of many plants

\footnotetext{
* Correspondence: ragabelmergawi05@hotmail.com

${ }^{1}$ Botany Department, National Research Centre, Giza 12622, Egypt Full list of author information is available at the end of the article
}

provided great inhibition on weed germination and growth (Al-Humaid and El-Mergawi 2014; Gomes et al. 2016; Rawat et al. 2017; Shah et al. 2018).

The Kingdom of Saudi Arabia exhibits a typical arid to semi-arid climate, and xerophytic vegetation makes up the prominent features of plant life (Zahran 1982). This vegetation is characterized by its unique biological diversity and species that have become acclimatized to grow under abiotic stress including hot temperatures and dry conditions. A number of native plants in this region have been reported to have allelopathic effects against different weed species (Al-Humaid and Warrag 1998; El-Mergawi and Al-Humaid 2017). In a previous study, we found that the extracts of seven native plants, Pulicaria undulata, Prosopis juliflora, Rumex vesicarius, Teucrium baccatus, Anvillea garcinii, Artemisia monosperma, and Withania somnifera, had the stronger inhibitory effect on germination of Portulaca oleracea, Echinochloa crusgalli, Phalaris minor, and Lactuca sativa seeds. Extracts of these 
plant species completely inhibited the germination of $P$. minor and P. oleracea at concentrations ranging from 10 to $40 \mathrm{~g} \mathrm{~L}^{-1}$ (Al-Humaid and El-Mergawi 2014).

The discovery of plant species with high allelopathic potentials provided a possibility for decreasing inputs in agricultural crop growing and for producing organic foods (Bashir et al. 2012). This requires thorough study of the effects of individual plant extract or plant component against weeds. In this study, we tested the allelopathic effects of extracts obtained from eight native plants against four target plants-Phalaris minor Retz, Echinochloa crusgalli L. Beauv, Portulaca oleracea L., and Lactuca sativa, under laboratory and greenhouse conditions.

\section{Materials and methods}

All experiments were conducted at Qassim University, Buraydah city, Saudi Arabia, since October 2013.

\section{Plant material and preparation}

Aerial parts of eight plants (Tamarix mannifera, Alhagi maurorum, Echinops spinosissimus, Haloxylon salicornicum, Lactuca virosa, Neurada procumbens, Ochradenus bacctus, and Cyperus conglomerates) were collected at the flowering stage from Al-Qassim region, Saudi Arabia. These plant species are widespread as wild plants in El-Qassim, Saudi Arabia desert. Vegetative parts were immediately dried in open trays in a laboratory-drying oven at $60^{\circ} \mathrm{C}$ and then ground into a powder and passed through a 40-mesh sieve with a particle diameter of less $0.35 \mathrm{~mm}$. Dried materials were stored in tightly closed plastic containers to maintain dryness until extraction.

\section{Extract preparation}

Methanol extracts from ground vegetative parts were obtained by weighing $100 \mathrm{~g}$ of dried plant material into a flask containing $1.0 \mathrm{~L}$ of methanol. The flasks were shaken on an orbital shaker at 150-rpm agitation speed for $24 \mathrm{~h}$ at room temperature. The extracts were then filtered through a Whatman No. 1 filter paper. Methanol extracts were evaporated using a rotary evaporator at $40^{\circ} \mathrm{C}$ using Rotavapor R-114 (Buchi, France), and the residues were weighed. Yields of extracts (\%) were expressed as g residue $/ 100 \mathrm{~g}$ dried plant material. The residues were dissolved in $1.0 \mathrm{~L}$ methanol to obtain a stock extract concentration equivalent to $100 \mathrm{~g}$ dried plant material/L of methanol. These original extracts were stored in a refrigerator at $4{ }^{\circ} \mathrm{C}$ until further dilution and bioassay.

\section{Germination bioassay}

A germination test was conducted using seeds of canary grass (Phalaris minor Retz), barnyard grass (Echinochloa crusgalli L. Beauv), and purslane (Portulaca oleracea L.) collected from agricultural fields. These target plants were chosen because they represent a range of grasses and broadleaf weed species. In addition, Lactuca sativa plant has been commonly used in allelopathic studies. Seeds of L. sativa were purchased from Modesto Seed Co., INC, USA. Seeds were surface-sterilized with sodium hypochlorite $(0.1 \%, w / v)$ for $2 \mathrm{~min}$, washed under running tap water for $5 \mathrm{~min}$ followed by distilled water for $2 \mathrm{~min}$, and stored for further use.

The stock methanol extract $(100 \mathrm{~g} / \mathrm{L})$ was diluted with methanol to obtain final concentrations of $5,10,20$, and $40 \mathrm{~g} / \mathrm{L}(w / v)$. Methanol extract $(4 \mathrm{~mL})$ was placed in a 9-cm plastic Petri dish lined with a single Whatman No. 1 filter paper and evaporated to dryness for $24 \mathrm{~h}$ at $24^{\circ} \mathrm{C}$. Methanol $(4 \mathrm{~mL})$ was applied to a Petri dish to serve as a control. After evaporation, $4 \mathrm{~mL}$ of distilled water were added onto the filter paper. Twenty seeds were placed on the paper in the Petri dishes. Four replicate Petri dishes of each treatment were placed, in a completely randomized manner, in a growth chamber at $25^{\circ} \mathrm{C}$. After 7 days, germination percent, shoot length, and root length of germinated seeds were determined. Data were expressed in \% of control for each treatment using the following equation:

$$
\% \text { of control }=(\text { Treatment } / \text { Control }) \times 100
$$

\section{Greenhouse bioassay}

Another experiment was performed to study the effect of the eight plant extracts on 6-week-old P. minor, E. crusgalli, $P$. oleracea, and $L$. sativa plants raised under controlled conditions in an experimental greenhouse $\left(25 \pm 3{ }^{\circ} \mathrm{C}, 12 \mathrm{~h}\right.$ photoperiod). Methanol extracts at four concentrations $(0,30,60$, and $90 \mathrm{~g} / \mathrm{L})$ were used in a phototoxic bioassay after evaporating the methanol and dissolving the residue in DMSO-water solution $(1 \%, v / v)$. Plants were raised from the collected seeds in $12-\mathrm{cm}$ diameter earthenware pots. The pots were filled with $750 \mathrm{~g}$ soil (sand: peat moss, 3:1, w/w), and 20 seeds of each plant species were sown per pot. Two weeks after emergence, pots were watered daily, and after 3 weeks, they were flushed with half-strength Hoagland solution. When plants were 6 weeks old, they were sprayed with plant extracts at $0,3,6$, and $9 \%(w / v)$ concentrations using a common garden sprayer at the rate of $100 \mathrm{~mL} /$ $\mathrm{m}^{2}$. Four replicates of each treatment were placed in a completely randomized manner. Seven days after the extracts were sprayed onto the plants, the plants were examined for visible injury levels and the percent of chlorotic and necrotic areas were recorded.

\section{Statistical analysis}

Analyses were performed in triplicate. Analysis of variance and comparison of treatment means (LSD, $5 \%$ level) were performed using Stat graphics Plus Version 5.1. 


\section{Results}

\section{Germination bioassay}

The effects of methanol extract of eight native plants on germination percentage and seedling growth of $P$. minor, E. crusgalli, P. oleracea and $L$. sativa plants were determined at 5, 10, 20 and $40 \mathrm{~g} / \mathrm{L}$ (Tables 1, 2, and 3).

\section{Effect of plant extracts on germination percentage}

The germination of $P$. minor was inhibited by the extracts in all test concentrations, and the degree of inhibition increased with increased extract concentrations (Table 1). At the highest concentration $(40 \mathrm{~g} / \mathrm{L})$, germination of $P$. minor exhibited great inhibition as affected by the extracts of $T$. mannifera (100\%), A. maurorum (65\%), E. spinosissimus (85\%), H. salicornicum (67\%), L. virosa (95\%), N. procumbens (71\%), and O. bacctus (73\%). With less extent, the effects of different plant extracts on germination of $P$. oleracea were similar to those seen on the germination of $P$. minor. The highest reduction effect on germination of $P$. oleracea was obtained with T. mannifera and L. virosa at $40 \mathrm{~g} / \mathrm{L}$ (reached $87 \%$ and $94 \%$, respectively).

Germination of E. crusgalli and L. sativa seeds possessed the least inhibitory effect (Table 1). The most inhibition effect on E. crusgalli germination was obtained by $L$. virosa and C. conglomerates extracts at $20 \mathrm{~g} / \mathrm{L}$ and $40 \mathrm{~g} / \mathrm{L}$. As for L. sativa, using different extracts at low

Table 1 Effect of plant extracts (\% of control) on germination percentage of P. minor, P. oleracea, E crusgalli, and L. sativa

\begin{tabular}{|c|c|c|c|c|c|c|c|c|}
\hline \multirow[t]{2}{*}{ Plant species } & \multicolumn{8}{|c|}{ Extract concentration $(\mathrm{g} / \mathrm{L})$} \\
\hline & 5 & 10 & 20 & 40 & 5 & 10 & 20 & 40 \\
\hline & \multicolumn{4}{|c|}{ P. minor } & \multicolumn{4}{|c|}{ P. oleracea } \\
\hline T. mannifera & $68^{*}$ & $55^{*}$ & $42^{*}$ & $0^{*}$ & $77^{*}$ & $68^{*}$ & $40^{*}$ & $13^{*}$ \\
\hline A. maurorum & $50^{*}$ & $44^{*}$ & $38^{*}$ & $35^{*}$ & $73^{*}$ & $71^{*}$ & $70^{*}$ & $62^{*}$ \\
\hline E. spinosissimus & $56^{*}$ & $41^{*}$ & $27^{*}$ & $15^{*}$ & 93 & $82^{*}$ & $78^{*}$ & $67^{*}$ \\
\hline H. salicornicum & $87^{*}$ & $71^{*}$ & $47^{*}$ & $33^{*}$ & 89 & $85^{*}$ & 87 & $49^{*}$ \\
\hline L. virosa & 98 & 91 & $67^{*}$ & $5^{*}$ & 100 & 97 & 97 & $6^{*}$ \\
\hline N. procumbens & $68^{*}$ & $44^{*}$ & $38^{*}$ & $29^{*}$ & 96 & $80^{*}$ & $80^{*}$ & $76^{*}$ \\
\hline O. bacctus & $87^{*}$ & $70^{*}$ & $67^{*}$ & $27^{*}$ & 92 & 88 & $80^{*}$ & $74^{*}$ \\
\hline \multirow[t]{2}{*}{ C. conglomerates } & 98 & 91 & $81^{*}$ & $81^{*}$ & 100 & 100 & 100 & $67^{*}$ \\
\hline & \multicolumn{4}{|c|}{ E. crusgalli } & \multicolumn{4}{|c|}{ L. sativa } \\
\hline T. mannifera & 100 & 100 & $85^{*}$ & $7^{8 *}$ & 100 & 89 & $24^{*}$ & $21^{*}$ \\
\hline A. maurorum & 100 & 92 & 89 & $81^{*}$ & 100 & 94 & 87 & $84^{*}$ \\
\hline E. spinosissimus & 100 & 87 & 89 & $81^{*}$ & 100 & 96 & 100 & 88 \\
\hline H. salicornicum & 97 & $80^{*}$ & $80^{*}$ & $70^{*}$ & 99 & 100 & 93 & $54^{*}$ \\
\hline L. virosa & 100 & 98 & $60^{*}$ & $57^{*}$ & 100 & 97 & 100 & 100 \\
\hline N. procumbens & 100 & 100 & $84^{*}$ & $78^{*}$ & 100 & 100 & 100 & 99 \\
\hline O. bacctus & 88 & $70^{*}$ & $73^{*}$ & $68^{*}$ & 100 & 100 & 100 & 97 \\
\hline C. conglomerates & $83^{*}$ & $81^{*}$ & $62^{*}$ & $57^{*}$ & 98 & 99 & 95 & $62^{*}$ \\
\hline
\end{tabular}

*Values significantly less than the respective control $(p \leq 0.05)$
Table 2 Effect of plant extracts (\% of control) on shoot length of P. minor, P. oleracea, E crusgalli, and L. sativa

\begin{tabular}{|c|c|c|c|c|c|c|c|c|}
\hline \multirow[t]{2}{*}{ Plant species } & \multicolumn{8}{|c|}{ Extract concentration $(\mathrm{g} / \mathrm{L})$} \\
\hline & 5 & 10 & 20 & 40 & 5 & 10 & 20 & 40 \\
\hline & \multicolumn{4}{|c|}{ P. minor } & \multicolumn{4}{|c|}{ P. oleracea } \\
\hline T. mannifera & 99 & $46^{*}$ & $10^{*}$ & $0^{*}$ & $80^{*}$ & $66^{*}$ & $35^{*}$ & $0^{*}$ \\
\hline A. maurorum & $35^{*}$ & $27^{*}$ & $13^{*}$ & $0^{*}$ & $65^{*}$ & $50^{*}$ & $48^{*}$ & $46^{*}$ \\
\hline E. spinosissimus & $53^{*}$ & $25^{*}$ & $8^{*}$ & $0^{*}$ & 86 & $66^{*}$ & $61^{*}$ & $59^{*}$ \\
\hline H. salicornicum & $73^{*}$ & $30^{*}$ & $24^{*}$ & $0^{*}$ & 92 & 90 & $75^{*}$ & $28^{*}$ \\
\hline L. virosa & $64^{*}$ & $36^{*}$ & $37^{*}$ & $0^{*}$ & 100 & 96 & $66^{*}$ & $0^{*}$ \\
\hline N. procumbens & $12^{*}$ & $10^{*}$ & $10^{*}$ & $0^{*}$ & 87 & $71^{*}$ & $65^{*}$ & $52^{*}$ \\
\hline O. bacctus & $71^{*}$ & $70^{*}$ & $46^{*}$ & $21^{*}$ & $128^{*}$ & $124^{*}$ & $121^{*}$ & 121 \\
\hline \multirow[t]{2}{*}{ C. conglomerates } & 94 & $78^{*}$ & $69^{*}$ & $36^{*}$ & $143^{*}$ & $128^{*}$ & 97 & $47^{*}$ \\
\hline & \multicolumn{4}{|c|}{ E. crusgalli } & \multicolumn{4}{|c|}{ L. sativa } \\
\hline T. mannifera & $71^{*}$ & $42^{*}$ & $35^{*}$ & $25^{*}$ & $119^{*}$ & 104 & $39^{*}$ & $24^{*}$ \\
\hline A. maurorum & 96 & 88 & $68^{*}$ & $47^{*}$ & $118^{*}$ & 110 & 96 & 88 \\
\hline E. spinosissimus & 91 & 90 & $84^{*}$ & $69^{*}$ & $118^{*}$ & 102 & 96 & 89 \\
\hline H. salicornicum & $67^{*}$ & $56^{*}$ & $40^{*}$ & $36^{*}$ & $148^{*}$ & $159^{*}$ & $115^{*}$ & $75^{*}$ \\
\hline L. virosa & 96 & $86^{*}$ & $44^{*}$ & $36^{*}$ & $143^{*}$ & $127^{*}$ & 112 & 87 \\
\hline N. procumbens & 110 & $87^{*}$ & 89 & $41^{*}$ & $119^{*}$ & 107 & 90 & $83^{*}$ \\
\hline O. bacctus & $75^{*}$ & $73^{*}$ & $61^{*}$ & $49^{*}$ & $120^{*}$ & $118^{*}$ & 110 & 108 \\
\hline C. conglomerates & 97 & $73^{*}$ & $72^{*}$ & $37^{*}$ & $130^{*}$ & $143^{*}$ & $140^{*}$ & 93 \\
\hline
\end{tabular}

*Values significantly less than the respective control $(p \leq 0.05)$

Table 3 Effect of plant extracts (\% of control) on root length of P. minor, P. oleracea, E crusgalli, and L. sativa

\begin{tabular}{|c|c|c|c|c|c|c|c|c|}
\hline \multirow[t]{2}{*}{ Plant species } & \multicolumn{8}{|c|}{ Extract concentration $(\mathrm{g} / \mathrm{L})$} \\
\hline & 5 & 10 & 20 & 40 & 5 & 10 & 20 & 40 \\
\hline & \multicolumn{4}{|c|}{ P. minor } & \multicolumn{4}{|c|}{ P. oleracea } \\
\hline T. mannifera & 89 & $25^{*}$ & $3^{*}$ & $0^{*}$ & $80^{*}$ & $84^{*}$ & $29^{*}$ & $10^{*}$ \\
\hline maurorum & $37^{*}$ & $25^{*}$ & $10^{*}$ & $0^{*}$ & $41^{*}$ & $40^{*}$ & $36^{*}$ & $33^{*}$ \\
\hline E. spinosissimus & $52^{*}$ & $26^{*}$ & $8^{*}$ & $0^{*}$ & 90 & $57^{*}$ & $50^{*}$ & $50^{*}$ \\
\hline H. salicornicum & $26^{*}$ & $12^{*}$ & $7^{*}$ & $0^{*}$ & 109 & $80^{*}$ & $57^{*}$ & $7^{*}$ \\
\hline virosa & $63^{*}$ & $25^{*}$ & $26^{*}$ & $0^{*}$ & 113 & $73^{*}$ & $72^{*}$ & $0^{*}$ \\
\hline 1. procumbens & $5^{*}$ & $5^{*}$ & $3^{*}$ & $0^{*}$ & $80^{*}$ & $75^{*}$ & $55^{*}$ & $55^{*}$ \\
\hline hasctus & $59^{*}$ & $48^{*}$ & $39^{*}$ & $10^{*}$ & $145^{*}$ & 108 & 108 & 108 \\
\hline \multirow[t]{2}{*}{ C. conglomerates } & $71^{*}$ & $58^{*}$ & $39^{*}$ & $37^{*}$ & $135^{*}$ & $127^{*}$ & 90 & $45^{*}$ \\
\hline & \multicolumn{4}{|c|}{ E. crusgalli } & \multicolumn{4}{|c|}{ L. sativa } \\
\hline T. mannifera & $43^{*}$ & $23^{*}$ & $8^{*}$ & $0^{*}$ & $85^{*}$ & $57^{*}$ & $10^{*}$ & $0^{*}$ \\
\hline A. maurorum & $79^{*}$ & $43^{*}$ & $21^{*}$ & $19^{*}$ & 88 & $75^{*}$ & $65^{*}$ & $33^{*}$ \\
\hline E. spinosissimus & $70^{*}$ & $55^{*}$ & $48^{*}$ & $46^{*}$ & $83^{*}$ & 95 & $73^{*}$ & $70^{*}$ \\
\hline H. salicornicum & $22^{*}$ & $18^{*}$ & $12^{*}$ & $7^{*}$ & 107 & 105 & 91 & $26^{*}$ \\
\hline L. virosa & 89 & $71^{*}$ & $19^{*}$ & $6^{*}$ & 91 & $68^{*}$ & $15^{*}$ & $11^{*}$ \\
\hline N. procumbens & $72^{*}$ & $61^{*}$ & $52^{*}$ & $16^{*}$ & $47^{*}$ & $43^{*}$ & $53^{*}$ & $16^{*}$ \\
\hline O. bacctus & $47^{*}$ & $26^{*}$ & $22^{*}$ & $14^{*}$ & $124^{*}$ & 107 & 103 & 101 \\
\hline C. conglomerates & 99 & $71^{*}$ & $52^{*}$ & $12^{*}$ & $85^{*}$ & $58^{*}$ & $66^{*}$ & $37^{*}$ \\
\hline
\end{tabular}

*Values significantly less than the respective control $(p \leq 0.05)$ 
concentrations $(5-20 \mathrm{~g} / \mathrm{L})$ did not produce any significant effect on germination percentage, except the inhibition effect of T. mannifera extract at $20 \mathrm{~g} / \mathrm{L}$. However, at the highest concentration, $T$. mannifera, $H$. salicornicum, and C. conglomerates reduced germination of $L$. sativa by $79 \%, 46 \%$, and $38 \%$, respectively.

\section{Effect of plant extracts on shoot length}

Data in Table 2 indicated that shoot growth of target seeds varied greatly in their response to examine extracts, and $P$. minor achieved the greatest sensitivity. All plant extracts resulted in remarkable reduction in shoot length of $P$. minor, and the degree of reduction increased as the extract concentration increased. The inhibition effects ranged between 22 and $90 \%$ at $10 \mathrm{~g} / \mathrm{L}$ as well as between 31 and $92 \%$ at $20 \mathrm{~g} / \mathrm{L}$. By increasing the concentration to $40 \mathrm{~g} / \mathrm{L}$, extracts of $T$. mannifera, $A$. maurorum, E. spinosissimus, $H$. salicornicum, $L$. virosa, and $N$. procumbens completely inhibited shoot growth of $P$. minor. The inhibition effect on shoot length of $P$. oleracea was somewhat lower than that observed for $P$. minor. Except the consistent stimulation effects obtained by $O$. bacctus and $C$. conglomerates, all plant extracts reduced shoot length of $P$. oleracea at all tested concentrations. However, a complete inhibition was obtained by using extracts of T. mannifera and $L$. virosa at $40 \mathrm{~g} / \mathrm{L}$.

As for E. crusgalli seeds, the extracts inhibited shoot elongation at all test concentrations and the degree of inhibition increased by increasing the extract concentration (Table 2). At the highest concentration $(40 \mathrm{~g} / \mathrm{L})$, the greatest inhibition effects on shoot length of $E$. crusgalli were recorded at $40 \mathrm{~g} / \mathrm{L}$ for all tested extracts, especially T. mannifera (75\%). Data in Table 2 indicated that $L$. sativa seeds possessed the least inhibitory as compared with other examine seeds. Whereas, all extracts stimulated the shoot growth of L. sativa at 5 and $10 \mathrm{~g} / \mathrm{L}$, ranging between $2 \%$ and $59 \%$ when compared with the control. With increasing concentration to $20 \mathrm{~g} / \mathrm{L}$, many of plant extracts continued to cause a stimulatory effect. However, the greatest inhibitory effect on shoot growth of L. sativa was obtained by $T$. mannifera at $20 \mathrm{~g} / \mathrm{L}$ $(61 \%)$ and at $40 \mathrm{~g} / \mathrm{L}(76 \%)$.

\section{Effect of plant extracts on root length}

The results indicated that the effects of plant extracts on the root length of target seeds were concentration and species-dependent (Table 3). The inhibitory effect of the test extracts varied among the four seed species examined. Methanol extract of tested plants inhibited root growth of $P$. minor at all concentrations when compared with control. Extracts of T. mannifera, A. maurorum, $E$. spinosissimus, H. salicornicum, L. virosa, and N. procumbens caused more than $70 \%$ reduction in root length of P. minor when applied at 10 or $20 \mathrm{~g} / \mathrm{L}$. By increasing concentration to $40 \mathrm{~g} / \mathrm{L}$, these extracts resulted in a complete inhibition on root growth of $P$. minor. The response of $E$. crusgalli to test extracts was similar to that of $P$. minor. Root growth of $E$. crusgalli was greatly affected by different plant extracts at all tested concentrations. At high concentrations $(20$ and $40 \mathrm{~g} / \mathrm{L}), T$. mannifera inhibited the root growth of E. crusgalli with $92 \%$ and $100 \%$, respectively.

The root growth of $P$. oleracea and $L$. sativa was exhibited less sensitive to the extracts than $P$. minor and $E$. crusgalli (Table 3). At low doses, plant extracts had inhibitory and stimulatory effects on root length of $P$. oleracea and $L$. sativa. The extracts of $O$. bacctus continued to stimulate root elongation of two seeds at all tested concentrations. Except for O. bacctus, all examined extracts reduced root length of $P$. oleracea and $L$. sativa at $20 \mathrm{~g} / \mathrm{L}$, particularly $T$. mannifera extract $(71 \%$ and $90 \%$, respectively). Whereas maximum inhibition effect on root length of $P$. oleracea and $L$. sativa was obtained at $40 \mathrm{~g} / \mathrm{L}$, especially for extracts of T. mannifera $(90 \%$ and $100 \%$, respectively), H. salicornicum ( $93 \%$ and $74 \%$, respectively), and $L$. virosa (100\% and $89 \%$, respectively).

\section{Greenhouse bioassay}

The inhibitory activity of methanol extract from eight native plants on growth of 6-week old of $P$. minor, $E$. crusgalli, $P$. oleracea, and $L$. sativa was determined at 30, 60, and $90 \mathrm{~g} / \mathrm{L}$ (Table 4). In general, the growth of 6-week-old plants was less sensitive to the test extracts than the seed germination. Except for T. mannifera, foliar spray of tested extracts at all examined concentrations did not produce any significant reduction on growth of four target plants, whereas using $T$. mannifera extract at $60 \mathrm{~g} / \mathrm{L}$ or $90 \mathrm{~g} / \mathrm{L}$ inhibited growth of $P$. minor, E. crusgalli, and Lactuca sativa between 13 and 25\%.

\section{Discussion}

Methanol extract of eight plants had the ability to affect germination percent and seedling growth of both monocotyledonous species ( $P$. minor and $E$. crusgalli) and dicotyledonous species ( $P$. oleracea and $L$. sativa), under laboratory condition. The inhibitory effect of the test extracts varied among the four seed species examined, and $P$. minor was more sensitive to tested extracts than $P$. oleracea, E. crusgalli, and L. sativa. Similar observation was reported by Al-Humaid and El-Mergawi (2014). Moreover, we found that the effectiveness of extracts on the root growth was apparently greater than that on the germination percent or shoot growth of the same tested seeds. This is in agreement with Turk and Tawaha (2002), in which they reported that extracts of allelopathic plants generally have more pronounced effects on root, rather than shoot, growth. This may be attributed to the fact that roots are the first to absorb the 
Table 4 Effect of plant extracts (\% of control) on growth of 6week-old P. minor, P. oleracea, E crusgalli, and L. sativa

\begin{tabular}{|c|c|c|c|c|c|c|}
\hline \multirow[t]{2}{*}{ Plant species } & \multicolumn{6}{|c|}{ Extract concentration $(\mathrm{g} / \mathrm{L})$} \\
\hline & 30 & 60 & 90 & 30 & 60 & 90 \\
\hline & \multicolumn{3}{|c|}{ P. minor } & \multicolumn{3}{|c|}{ P. oleracea } \\
\hline T. mannifera & 87 & $85^{*}$ & $75^{*}$ & 92 & 95 & 92 \\
\hline A.maurorum & 95 & 92 & 92 & 97 & 97 & 96 \\
\hline E. spinosissimus & 95 & 94 & 92 & 97 & 99 & 94 \\
\hline H. salicornicum & 93 & 94 & 92 & 98 & 98 & 96 \\
\hline L. virosa & 94 & 96 & 94 & 96 & 96 & 95 \\
\hline N. procumbens & 95 & 93 & 95 & 97 & 96 & 97 \\
\hline O. bacctus & 95 & 96 & 96 & 96 & 97 & 97 \\
\hline \multirow[t]{2}{*}{ C. conglomerates } & 97 & 94 & 95 & 99 & 97 & 98 \\
\hline & \multicolumn{3}{|c|}{ E. crusgalli } & \multicolumn{3}{|c|}{ L. sativa } \\
\hline T. mannifera & 90 & $87^{*}$ & $82^{*}$ & 90 & $87^{*}$ & $82^{*}$ \\
\hline A.maurorum & 99 & 95 & 95 & 97 & 97 & 96 \\
\hline E. spinosissimus & 92 & 94 & 92 & 96 & 96 & 92 \\
\hline H. salicornicum & 95 & 95 & 95 & 94 & 95 & 93 \\
\hline L. virosa & 97 & 98 & 97 & 98 & 96 & 97 \\
\hline N. procumbens & 95 & 95 & 96 & 95 & 95 & 95 \\
\hline O. bacctus & 95 & 95 & 94 & 96 & 95 & 94 \\
\hline C. conglomerates & 95 & 94 & 94 & 97 & 97 & 94 \\
\hline
\end{tabular}

*Values significantly less than the respective control $(p \leq 0.05)$

allelochemicals or autotoxic compounds from the environment.

All species affect germination percentage and seedling growth of target seeds, in a dose-response relationship. It is evident that the most promising plants were $T$. mannifera and $L$. virosa due to their remarkable potency and their regularity in inhibiting both seed germination and seedling growth of target seeds. Using T. mannifera extract at $40 \mathrm{~g} / \mathrm{L}$ completely inhibited the germination and seedling growth of $P$. minor, shoot length of $P$. oleracea, and root length of $E$. crusgalli and $L$. sativa seeds. Moreover, at $40 \mathrm{~g} / \mathrm{L}, L$. virosa nearly had a complete inhibition on germination and seedling growth of $P$. minor and $P$. oleracea and caused a great inhibition on seedling growth of E. crusgalli and L. sativa seeds. Inhibition of plant extracts on the seed germination process is thought to be related to osmotic effects on the rate of imbibition, which then inhibits the initiation of germination and, especially, the cell elongation (Black 1989). Such inhibitory effects led to suggest that extracts of these plants likely contain allelochemicals as phenolics and terpenoids (Wesołowska et al. 2006; Stojakowska et al. 2012). On the contrary, at low concentration, many of plant extracts caused a remarkable stimulation effect on root and shoot growth of $P$. oleracea and $L$. sativa seeds, particularly at low concentration. The extract of $O$. bacctus stimulated shoot and root elongation of $L$. sativa at all tested concentrations. In line of these results, Narwal (1994) mentioned that allelochemicals that inhibit the growth of some species at certain concentration might stimulate the growth of the same or different species at different concentrations. Generally, allelopathic effects are not totally inhibitory; they depend on the developmental stages or target species (Otusanya et al. 2008) or the concentration of the extract (He et al. 2009). Not all allelochemical substances are inhibitors; they can be stimulants, like mineral nutrients, organic acids, carbohydrates, and growth regulators (Tukey Junior 1969). It is essential to identify the concentration of which each specific response occurs if allelopathic interaction is to be used in weed management program.

The greenhouse experiment provided further evidence for the great allelopathic potential, observed in laboratory, for T. mannifera extract. Using this extract at $60 \mathrm{~g} / \mathrm{L}$ and $90 \mathrm{~g} / \mathrm{L}$ significantly reduced growth of 6-week-old P. minor, E. crusgalli, and L. sativa plants. The inhibition effect may occur through a variety of mechanisms including suppressed hormone activity, reduced rate of ion uptake, inhibition of some physiological process (as photosynthesis, respiration, and protein formation), decreased permeability of cell membranes, and/or inhibition of enzyme action (Rice 1974). In general, the growth of 6-week-old weeds (Table 4) tended to be less sensitive to the test extracts than the weed germination (Tables 1, 2, 3, and 4). Inderjit and Weston (2000) reported that greenhouse bioassays do not adequately predict the responses observed in laboratory bioassay. Thus, the seedling stage and the more mature stage of target plants vary in their sensitivities to plant extracts (Reigosa et al. 1999). Hence, weed germination might be the most sensitive index with which to judge allelopathy of tested extracts under natural conditions (Coree et al. 2008).

\section{Conclusions}

We examined the allelopathic effects of eight native plants from the Al-Qassim region of Saudi Arabia on seed germination and growth of 6-week-old plants of $P$. minor, E. crusgalli, $P$. oleracea, and $L$. sativa. The effectiveness of extracts depended on the target plants, extract concentrations, and test plant species. Extracts of $T$. mannifera and $L$. virosa were capable of inhibiting seed germination and seedling growth of target species, especially at high concentrations. In general, the growth of 6-week-old plants was less sensitive to the test extracts than the seed germination. The only significant reduction in growth of target plants was obtained by T. mannifera extract. Generally, the extracts of T. mannifera and $L$. virosa could yield pure, active compounds with potencies sufficient to the development of new herbicidal substances. 


\section{Acknowledgements}

The authors thank Promising Research Centre in Biological Control and Agricultural Information (BCARC), Qassim University, Saudi Arabia for financial support.

\section{Funding}

There are currently no funding sources in the design of the study and collection, analysis, and interpretation of data and in writing the manuscript.

\section{Availability of data and materials}

The datasets generated during and/or analysed during the current study are included in this manuscript.

\section{Authors' contributions}

RAEl-M performed the laboratory analysis and wrote the paper and AAl-H performed the data coordinated the data collection. Both authors read and approved the final manuscript.

\section{Ethics approval and consent to participate}

Not applicable.

\section{Consent for publication}

Not applicable.

\section{Competing interests}

The authors declare that they have no competing interests.

\section{Publisher's Note}

Springer Nature remains neutral with regard to jurisdictional claims in published maps and institutional affiliations.

\section{Author details}

${ }^{1}$ Botany Department, National Research Centre, Giza 12622, Egypt. ${ }^{2}$ Promising Research Centre in Biological Control and Agricultural Information (BCARC), Qassim University, Buraidah, Saudi Arabia.

Received: 3 July 2018 Accepted: 25 January 2019

Published online: 06 February 2019

\section{References}

Al-Humaid A, El-Mergawi RA (2014) Herbicidal activities of seven native plants on the germination and growth of Phalaris minor, Echinochloa crusgalli, Portulaca oleracea and Lactuca sativa. J Agric Sci Tech A 4:843-852

Al-Humaid A, Warrag MO (1998) Effect of Mesquite (Prosopis juliflora) pericarps aqueous extracts on seed germination and plumule radical elongation of bermuda grass (Cynodon dactylon). J King Saud Univ Agric Sci 11:149-156

Bashir U, Javaid A, Bajwa R (2012) Allelopathic effects of sunflower residue on growth of rice and subsequent wheat crop. Chilean J Agric Res 72(3):326-331

Black M (1989) Seed research-past, present and future. In: Taylorson RB (ed) Recent advances in the development and germination of seeds. Plenum, New York, pp 1-6

Coree LR, Soares GLG, Fett-Neto AG (2008) Allelopathic potential of Psychotria leiocarpa, a dominant understory species of subtropical forests. South African J Bot 74:583-590

El-Mergawi R, Al-Humaid A (2017) Evaluation the allelopathic potential of fractions obtained from some native plants on Portulaca oleracea and Echinochloa crusgalli weed. Bull NRC 41:273-285

Gomes ACC, Gomes AKC, Magalhaes De PD, Buss DF, Simas NK, Kuster RM (2016) In vitro phytotoxic activity of Saccharum officinarum leaves on lettuce and weed Calopogonium mucunoides. Allelopathy J 39(2):177-190

He J, Lin J, Li J, Zhang JH, Sun XM, Zeng CM (2009) Dual effects of Ginkgo biloba leaf extract on human red blood cells. Basic Clin Pharm Toxicol 104:138-144

Inderjit M, Weston LA (2000) Are laboratory bioassays for allelopathy suitable for prediction of field response? J Chem Ecol 26:2111-2118

Masum SM, Hossain MA, Akamine H, Sakagami Jl, Bhowmik PC (2016) Allelopathic potential of indigenous Bangladeshi rice varieties. Weed Biol Manag 16(3):119-131

Narwal SS (1994) Allelopathy in crop production. Scientific Publishers, Jodhpur

Otusanya OO, Ikonoh OW, Ilori OJ (2008) Allelopathic potentials of Tithonia diversifolia (Hemsl) A. Gray: effect on the germination, growth and chlorophyll accumulation of Capsicum annum L. and Lycopersicon esculentum mill. Int J Bot 4:471-475
Putnam AR, Tang CS (1986) In: Putnam AR, Tang C-S (eds) The science of allelopathy. Wiley, New York, pp 1-22

Rawat LS, Maikhuri YM, Yateesh NK, Jha NK, Phondani PC (2017) Sunflower allelopathy for weed control in agriculture systems. J Crop Sci Biotech 20(1):45-60

Reigosa M, Sanchez-Moreiras A, Gonzalez L (1999) Eco physiological approach in allelopathy. Crit Rev Plant Sci 18:577-608

Rice EL (1974) Allelopathy. Academic Press, New York, p 353

Shah RH, Baloch MS, Khan AA, ljaz M, Zubair M (2018) Bioherbicidal assessment of aqueous extracts of mesquite (Prosopis juliflora) on weeds control and growth, yield and quality of wheat. Planta Daninha 36 (In press)

Stojakowska A, Malarz J, Szewczyk A, Kisiel W (2012) Caffeic acid derivatives from a hairy root culture of Lactuca virosa. Acta Physiol Plant 34:291-298

Trezzi MM, Vidal RA, Balbinot AA Jr, Von Hertwig Bettencourt H, da Silva Souza Filho AP (2016) Allelopathy: driving mechanisms governing its activity in agriculture. J Plant Interact 11(1):53-60

Tukey Junior HB (1969) Implications of allelopathy in agricultural plant science. Bot Rev 35:1-6

Turk MA, Tawaha AM (2002) Inhibitory effects of aqueous extracts of black mustard on germination and growth of lentil. Pak J Agron 1(1):28-30

Wesołowska A, Nikiforuk A, Michalska K, Kisiel W, Chojnacka W'j E (2006) Analgesic and sedative activities of lactucin and some lactucin-like guaianolides in mice. J Ethnopharmacol 107:254-258

Zahran M (1982) Vegetation types of Saudi Arabia. King Abdel Aziz University Press, Jeddah

\section{Submit your manuscript to a SpringerOpen ${ }^{\circ}$ journal and benefit from:}

- Convenient online submission

- Rigorous peer review

- Open access: articles freely available online

High visibility within the field

- Retaining the copyright to your article

Submit your next manuscript at $\boldsymbol{\nabla}$ springeropen.com 